\title{
Prevalence and diagnosis of bacterial kidney disease (BKD) in Scotland between 1990 and 2002
}

\author{
David W. Bruno* \\ FRS Marine Laboratory, PO Box 101, 375 Victoria Road, Aberdeen AB11 9DB, UK
}

\begin{abstract}
Bacterial kidney disease (BKD) is a notifiable disease for salmonids under United Kingdom and European Union legislation. Within the UK, legislation and the control of infected fish with BKD has been operating for $25 \mathrm{yr}$. Infection by the bacterium Renibacterium salmoninarum results in a chronic, debilitating infection and mortality. Records of BKD outbreaks and the detection of $R$. salmoninarum were monitored from 1990 through to 2002 for Atlantic salmon Salmo salar and rainbow trout Oncorhynchus mykiss reared in Scottish waters. The test methods included ELISA, culture and light microscopy. New outbreaks of BKD in salmon in seawater declined during this period, but with year-to-year variation. Only 1 record of BKD has occurred in freshwater-reared salmon (prevalence 1.04). BKD in farmed rainbow trout in seawater is uncommon and was only identified in 1993 and between 1998 and 2000. The number of active designated area orders (DAOs) for outbreaks in salmon has fallen since 1990, but has remained relatively constant for trout over the period of study.
\end{abstract}

KEY WORDS: Renibacterium salmoninarum $\cdot$ BKD $\cdot$ Prevalence $\cdot$ Scotland Resale or republication not permitted without written consent of the publisher

\section{INTRODUCTION}

Bacterial kidney disease (BKD) is a systemic, chronic, bacterial infection of salmonids in fresh and salt-water stages of their life cycle, and has been reported where salmonids are cultured or occur naturally, with the exception of Ireland, Australia, New Zealand and the former Soviet Union. The causative agent Renibacterium salmoninarum is a small, Grampositive, non-motile rod that is fastidious in its nutrient requirements (Austin et al. 1983). The bacterium is responsible annually for mortality in all age groups due to direct losses, and similarly from poor growth rates in chronically infected fish. Effective disease control continues to be problematic as antibiotics provide only temporary suppression of bacterial growth (Brown et al. 1990). The bacterium also occurs in reproductive fluids and remains viable intracellularly within host cells, sites that are difficult to target with conventional treatments. Furthermore, the bacterium can be transmitted horizontally from fish to fish and vertically within the egg (Evelyn et al. 1984, 1986, Bruno \& Munro 1986b). Variable protection using a live vaccine has been achieved (Griffiths et al. 1998, Piganelli et al. 1999, Daly et al. 2001). The bacterium can survive in freshwater and saltwater for a limited time, possibly within sediments and/or faecal matter. In addition, the presence of $R$. salmoninarum within tissue adhesions, attributed to adjuvant-reactions, may not be detected by light microscopy (Bruno \& Brown 1999).

Clinical signs of BKD included lethargy and darkening of the fish, exophthalmia, petechial haemorrhage, bloody ascites and enlargement of the kidney and spleen. White-grey granulomatous lesions are seen in the internal organs, generally in the kidney, and a creamy-coloured membrane may encapsulate the spleen, kidney, heart and other organs (Bruno 1986a).

Few long-term studies are published on epidemiological studies involving BKD outbreaks among farmed fish. The current work examines the occurrence and prevalence of BKD in Scottish stock between 1990 and 2002 and the current status of this disease within the Scottish fish farming. Conclusions are made on prevalence changes within the industry and the potential for continued control of BKD. 


\section{MATERIALS AND METHODS}

Gross pathology and a combination of enzymelinked immunosorbent assay (ELISA), culture and light microscopy were used to confirm BKD and the causative bacterium Renibacterium salmoninarum from wild and farmed fish. In most cases, each fish would be tested by all methods; however, in some cases not all tests were applied, for example, ELISA testing was not introduced until 1994

Light microscopy. Spleen, kidney, heart, liver, pyloric caeca and gills from moribund fish were fixed in buffered formal saline and tissue sections stained by haematoxylin and eosin (H\&E), Gram and Lillies allochrome, and examined by light microscopy. BKD was confirmed on the basis of typical lesions and the presence of small Gram-positive diplobacilli, and considered suspect when BKD-like lesions were recorded but without detection of the bacteria. H\&E staining was used to describe tissue pathology only, as this technique does not stain Renibacterium salmoninarum.

ELISA. ELISA testing for BKD is used as a diagnostic tool for the Fisheries Research Services (FRS) to quantify the level of soluble antigen (p57) in kidney tissue. Sample dilution buffer $(0.5 \mathrm{ml})$ was added to $5 \mathrm{~g}$ fish kidney tissue and macerated in a stomacher bag and processed according to manufacturer's instructions (DiagXotics). Positive ELISA results were based on kidney homogenates containing more than $10 \mathrm{ng} \mathrm{ml}^{-1}$ of the p57 antigen. ELISA results with values of 6.0 to $9.9 \mathrm{ng} \mathrm{ml}^{-1}$, when no other tests were available, constituted suspicion of the presence of BKD. Values below 5.9 were reported as negative.

Culture. Kidney tissue was streaked onto MuellerHinton medium containing $0.1 \%$ L-cysteine hydrochloride, $0.00125 \%$ D-cycloserine, $0.0025 \%$ polymyxin $\mathrm{B}$ sulphate and $0.00025 \%$ oxolinic acid $(\mathrm{MH})$ and was used to provide culture evidence of Renibacterium salmoninarum. Plates were incubated for 8 to $12 \mathrm{wk}$ at $15^{\circ} \mathrm{C}$ before discarding as negative. Positive growth on $\mathrm{MH}$ medium was evident as small, creamy-coloured, sticky colonies. API-ZYM profiles were conducted where necessary (bioMerieux). All $R$. salmoninarum isolates were coded, freeze-dried and incorporated into the FRS reference collection.

Fish-farm sampling. The level and intensity of official surveillance over the time period of this study has changed, and has to be taken into account when determining trends in incidence or prevalence of BKD in this industry. For example, between 1990 and 1995 a targeted surveillance programme for BKD was carried out, where each farm was visited once a year and a 30fish sample was tested for all List III diseases, including BKD. Since 1995, however, there has been no routine sampling programme for BKD on Scottish fish farms but all farms are inspected annually. Fish showing clinical signs of disease or abnormal mortality were sampled for this 12 yr survey.

A surveillance programme of wild salmon populations throughout Scotland was carried out to check for the presence of BKD in the same manner as farmed fish. In each year, 30 fish were sampled from 11 locations. The test locations varied such that all the major catchment areas were sampled over a 5 yr period. Prior to 1999 , only 5 areas were sampled each year. Additional sampling for BKD included wild fish sent to this laboratory for disease diagnosis.

The number of designated area orders (DAOs) in place represents a measure of farms that have confirmed BKD, or that have a significant epidemiological connection with an infected farm (e.g. as a consequence of an unauthorised movement of fish from an infected farm). For the purpose of this study, the number of farms under restriction with a DAO are used as an additional measure of BKD in the industry for each year. The number of active DAOs, including those new and withdrawn following a series of negative tests, are included. Atlantic salmon Salmo salar and rainbow trout Oncorhynchus mykiss data are analysed separately.

Positive results obtained by more than 1 method (i.e. ELISA, culture and biochemical testing or light microscopy) in any particular case were counted as a single result for the purpose of this study. Prevalence was calculated from the positive BKD cases in fresh- or saltwater relative to the total number of salmon or trout farms examined. Repeat positive test results from individual sites in any year were only recorded once.

\section{RESULTS}

The presence of Renibacterium salmoninarum, tissue pathology or presence of bacterial antigen was confirmed using a combination of light microscopy, ELISA, isolation of the bacterium on $\mathrm{MH}$ medium and biochemical properties. Gross signs represented presumptive diagnosis. There was a good correlation between the test methods using material from trout and salmon in freshwater and seawater. The biochemical profiles and tissue pathology for $R$. salmoninarum were consistent with published literature, and reference material held by FRS (Fryer \& Sanders 1981, Bruno \& Munro 1986a).

\section{Atlantic salmon}

Using the criteria outlined for the isolation of Renibacterium salmoninarum or soluble antigen, 26 cases of BKD were recorded in Atlantic salmon Salmo salar 
in seawater from 1990 to 2002 (Table 1). The incidence of new cases in seawater declined between 1990 and 1993, with a cluster of new cases particularly in 1998 (Fig. 1). During 1994 and 1995, 1997 and 2001, no new cases of BKD were identified. A diagnosis of BKD was made by light microscopy in a freshwater farm in 1992 and 2002, with a prevalence of 0.98 and 1.04, respectively (Fig. 2). Prevalence data for salmon in seawater are shown in Fig. 3 and show a downward trend from $1.22 \%$ in 1991 to $0.39 \%$ in 2002 . The number of DAOs placed for BKD in Scotland between 1990 and 2002 is presented in Fig. 4. Since 1990 the number of active DAOs for outbreaks in salmon has fallen, and figures show that there have been less than 8 in force since 1992. The revocations for salmon have ranged between 2 and 3 between 1992 and 2001, and 7 for 2002.

\section{Rainbow trout}

Between 1990 and 2002, 41 new cases of BKD were confirmed in farmed rainbow trout Oncorhynchus mykiss in Scotland using the methods identified above. The majority of outbreaks occurred in freshwater stock (Table 1). BKD in rainbow trout in seawater occurred sporadically; 1 case was recorded in 1993 and was confirmed by light microscopy; 2 to 8 new cases were recorded between 1998 and 2001 (Fig. 5). The data on outbreaks in freshwater are characterised by a cluster of new cases in 1993 to 1996 and 1998 to 2000 (Fig. 6). Testing indicated that some freshwater sites have seasonal outbreaks of BKD, in some cases exceeding 10 successive years. In contrast to salmon, the number of DAOs in force has remained relatively constant over the period of study, varying between 8 and 11 sites per year (Fig. 4). Furthermore, the number of new sites subject to a DAO has been very low, and has never exceeded more than 1 farm in any year. Likewise, the incidence of revocations of DAO is also low.
Table 1. Salmo salar and Oncorhynchus mykiss. Prevalence and testing for bacterial kidney disease by ELISA, culture and light microscopy between 1990 and 2002. NT: not tested

\begin{tabular}{|c|c|c|c|c|c|}
\hline Year & ELISA & Culture & $\begin{array}{c}\text { Light } \\
\text { microscopy }\end{array}$ & Total & Prevalence \\
\hline \multicolumn{6}{|c|}{ Atlantic salmon } \\
\hline \multicolumn{6}{|c|}{ Seawater } \\
\hline 1990 & NT & 0 & 6 & 6 & 0.66 \\
\hline 1991 & NT & 0 & 5 & 5 & 1.22 \\
\hline 1992 & NT & 2 & 2 & 2 & 1.06 \\
\hline 1993 & NT & 0 & 1 & 1 & 0.11 \\
\hline 1994 & 0 & 0 & 0 & 0 & 0.00 \\
\hline 1995 & 0 & 0 & 0 & 0 & 0.00 \\
\hline 1996 & 1 & 2 & 2 & 2 & 0.72 \\
\hline 1997 & 0 & 0 & 0 & 0 & 0.00 \\
\hline 1998 & 1 & 5 & 6 & 6 & 0.35 \\
\hline 1999 & 1 & 0 & 1 & 1 & 0.09 \\
\hline 2000 & 1 & 0 & 1 & 2 & 0.37 \\
\hline 2001 & 0 & 0 & 0 & 0 & 0.00 \\
\hline 2002 & 1 & 1 & 0 & 1 & 0.39 \\
\hline \multicolumn{6}{|c|}{ Freshwater } \\
\hline 1990 & NT & 0 & 0 & 0 & 0.00 \\
\hline 1991 & NT & 0 & 0 & 0 & 0.00 \\
\hline 1992 & NT & 0 & 1 & 1 & 1.04 \\
\hline 1993 & NT & 0 & 0 & 0 & 0.00 \\
\hline 1994 & 0 & 0 & 0 & 0 & 0.00 \\
\hline 1995 & 0 & 0 & 0 & 0 & 0.00 \\
\hline 1996 & 0 & 0 & 0 & 0 & 0.00 \\
\hline 1997 & 0 & 0 & 0 & 0 & 0.00 \\
\hline 1998 & 0 & 0 & 0 & 0 & 0.00 \\
\hline 1999 & 0 & 0 & 0 & 0 & 0.00 \\
\hline 2000 & 0 & 0 & 0 & 0 & 0.00 \\
\hline 2001 & 0 & 0 & 0 & 0 & 0.00 \\
\hline 2002 & 0 & 0 & 0 & 0 & 0.00 \\
\hline 2002 & 0 & 1 & 0 & 0 & 0.98 \\
\hline \multicolumn{6}{|c|}{ Rainbow trout } \\
\hline \multicolumn{6}{|c|}{ Seawater } \\
\hline 1990 & NT & 0 & 0 & 0 & 0.00 \\
\hline 1991 & NT & 0 & 0 & 0 & 0.00 \\
\hline 1992 & NT & 0 & 0 & 0 & 0.00 \\
\hline 1993 & NT & 1 & 0 & 1 & 33.30 \\
\hline 1994 & 0 & 0 & 0 & 0 & 0.00 \\
\hline 1995 & 0 & 0 & 0 & 0 & 0.00 \\
\hline 1996 & 0 & 0 & 0 & 0 & 0.00 \\
\hline 1997 & 0 & 0 & 0 & 0 & 0.00 \\
\hline 1998 & 3 & 1 & 0 & 3 & 10.00 \\
\hline 1999 & 8 & 5 & 8 & 8 & 10.53 \\
\hline 2000 & 2 & 1 & 0 & 2 & 18.20 \\
\hline 2001 & 0 & 0 & 0 & 0 & 0.00 \\
\hline 2002 & 0 & 0 & 0 & 0 & 0.00 \\
\hline \multicolumn{6}{|c|}{ Freshwater } \\
\hline 1990 & NT & 0 & 0 & 0 & 0.00 \\
\hline 1991 & NT & 0 & 0 & 0 & 0.00 \\
\hline 1992 & NT & 0 & 1 & 1 & 2.00 \\
\hline 1993 & NT & 4 & 3 & 4 & 6.63 \\
\hline 1994 & 2 & 2 & 0 & 2 & 1.26 \\
\hline 1995 & 2 & 4 & 1 & 4 & 5.00 \\
\hline 1996 & 0 & 0 & 0 & 0 & 0.00 \\
\hline 1997 & 0 & 0 & 0 & 0 & 0.00 \\
\hline 1998 & 6 & 2 & 0 & 6 & 6.45 \\
\hline 1999 & 7 & 5 & 3 & 7 & 7.61 \\
\hline 2000 & 3 & 2 & 0 & 3 & 8.11 \\
\hline 2001 & 0 & 0 & 0 & 0 & 0.00 \\
\hline 2002 & 0 & 1 & 0 & 0 & 0.98 \\
\hline
\end{tabular}




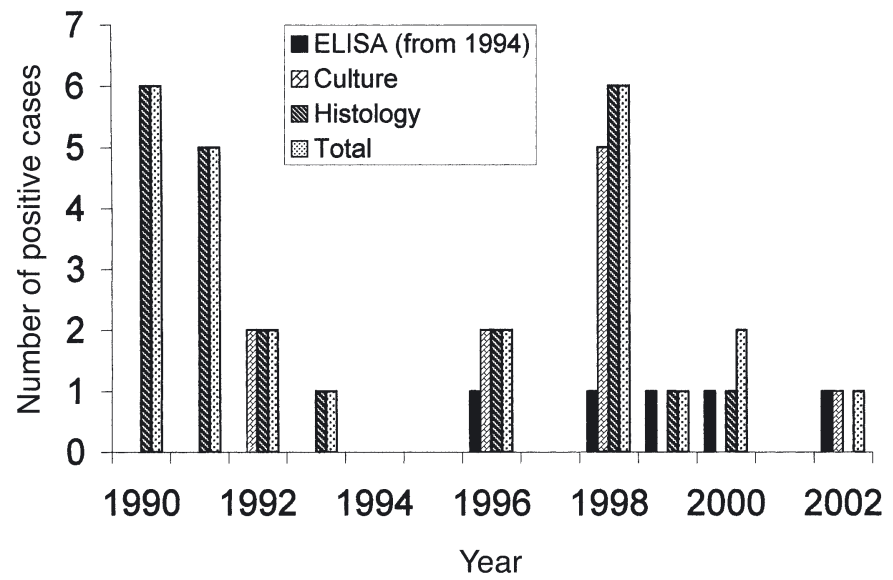

Fig. 1. Salmo salar. Diagnosis of bacterial kidney disease (BKD) in Atlantic salmon reared in seawater

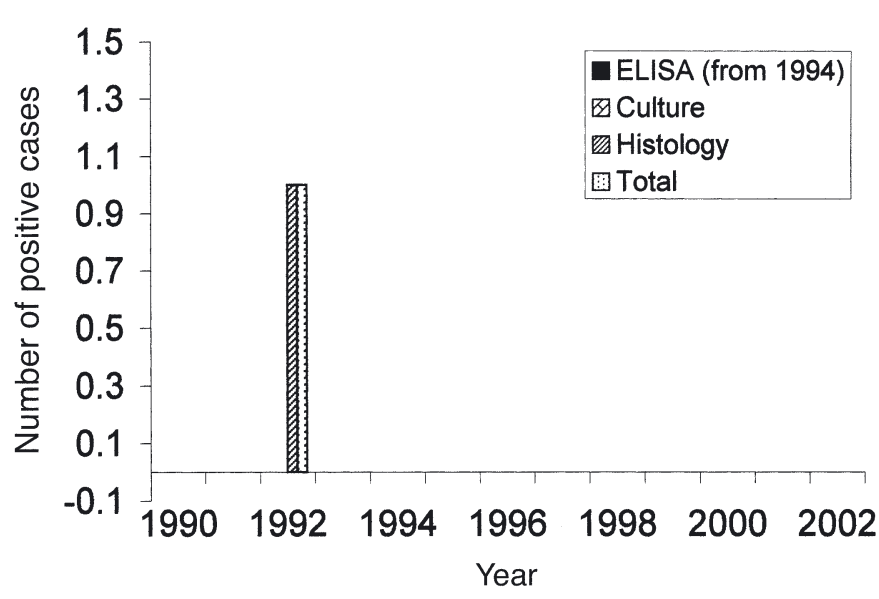

Fig. 2. Salmo salar. Diagnosis of bacterial kidney disease (BKD) in Atlantic salmon reared in freshwater

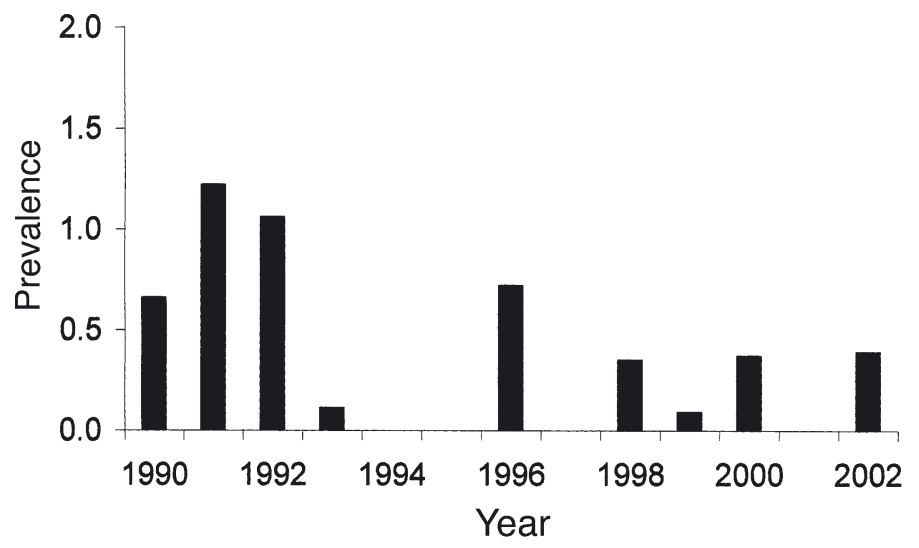

Fig. 3. Salmo salar. Prevalence of bacterial kidney disease (BKD) among Atlantic salmon in seawater

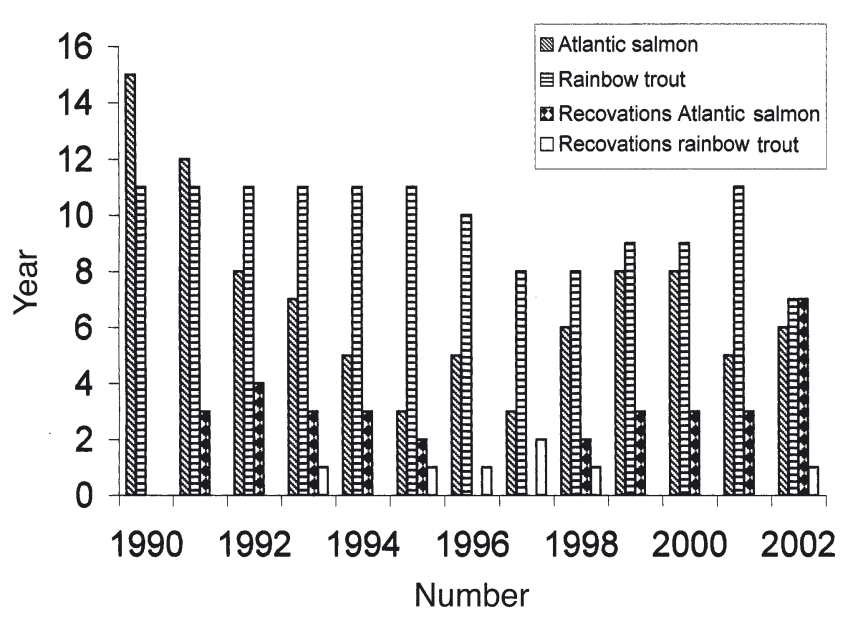

Fig. 4. Salmo salar and Oncorhynchus mykiss. Designated area orders (DAOs) and revocations inforce for bacterial kidney disease (BKD)

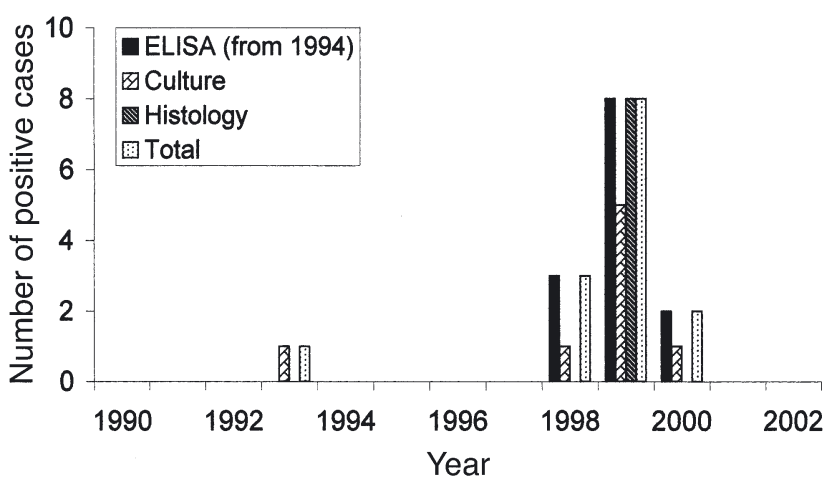

Fig. 5. Oncorhynchus mykiss. Diagnosis of bacterial kidney disease (BKD) in rainbow trout reared in seawater

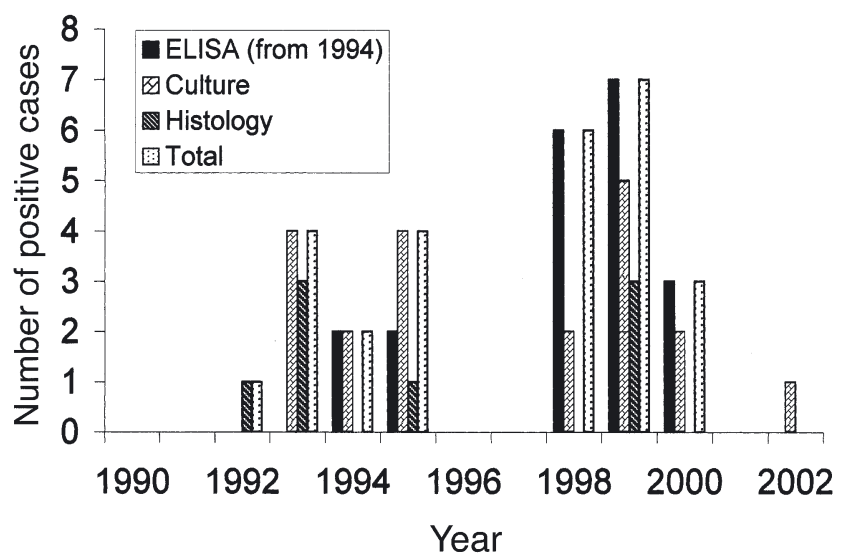

Fig. 6. Oncorhynchus mykiss. Diagnosis of bacterial kidney disease (BKD) in rainbow trout reared in freshwater 


\section{Wild fish sampling 1990 to 2002}

Despite regular surveillance since 1994, BKD has not been recorded in wild salmonids from Scotland and, furthermore, to our knowledge the last recorded case in wild fish occurred in the 1960s (Smith 1964).

\section{DISCUSSION}

BKD is a serious infectious disease for salmonids and effective control of infection is currently difficult to achieve (Elliott et al. 1989, Brown et al. 1990). Currently, disease surveillance and monitoring is focused on the detection of BKD as well as other notifiable fish diseases. Within FRS, testing for BKD involves several methods: culture on Mueller-Hinton medium, light microscopy and ELISA. The last-named technique was introduced to evaluate suspect BKD outbreaks quickly, instead of waiting extended periods for isolation of the bacterium by culture. In some cases not all tests were applied to each fish in each year, but in general there was agreement between test methods. A low level of infection or recovering fish during the summer months may not show bacteria within the tissue lesions and, hence, would be reported as a presumptive result. In these cases, confirmation would depend upon ELISA and/or culture.

Overall, data show a low prevalence of BKD in Scotland, with a sporadic occurrence since 1990 in salmon Salmo salar and rainbow trout Oncorhynchus mykiss. The prevalence of positive cases of BKD has remained low, with values of $<1.22$ for salmon and $<8.1$ for trout in freshwater. An earlier survey for BKD in farmed fish in Scotland covered the period 1976 to 1985 (Bruno 1986b), and this resulted in the detection of the first outbreak of BKD in Scotland in a rainbow trout hatchery. Consequently, BKD became a notifiable disease to the official service in 1978. During the 9 yr of that survey, BKD outbreaks occurred at 19 farms rearing rainbow trout and 5 farms rearing Atlantic salmon. The pattern of outbreaks appeared to be similar to that reported here for 1990 to 2002. For example, no new outbreaks of BKD were recorded in trout in freshwater in 1977 or 1978 , but thereafter, up to 1982,1 or 2 new farms per year became infected. In 1980, BKD was recorded in farmed salmon in potential S2 parr, and a year later this laboratory reported BKD in 1 sea winter salmon. In 1983, 7 new outbreaks of BKD were confirmed, followed by 3 cases in 1985, including BKDassociated mortality in rainbow trout reared in seawater. In the current study, BKD records for Scotland indicate an overall decline in prevalence since 1991 in fresh- and saltwater. The examination of the incidence of new cases shows a declining incidence between
1990 and 1993, and a cluster of cases between 1998 and 2000. This pattern of new cases is broadly reflected in changes in prevalence over time. BKD in rainbow trout in seawater is uncommon, and a reflection of industry practices with only 5 to 7 active marine rainbow trout farms in any year.

In the context of both farm and wild fisheries, BKD has a limited distribution within Scotland. However, outbreaks can pose a significant economic loss to cagecultured stock, and there is the potential for infection to impact wild populations. Evidence for the latter is, however, lacking, as surveys in Scotland fail to show evidence of BKD in wild fish. Historically, the first records of BKD occurred as 'Dee disease' in the 1930s in wild Atlantic salmon Salmo salar, including the River Dee in Aberdeenshire, Scotland (Smith 1964). Elsewhere, including Canada, USA, and Iceland, there are sporadic reports of infection by Renibacterium salmoninarum in wild fish (Pippy 1969, Mitchum et al. 1979, Banner et al. 1986, Jónsdóttir et al. 1998). Prevalence and severity of BKD in chinook salmon Oncorhynchus tshawytscha was examined by Maule et al. (1996) in western USA during release and seaward migration. They reported a decline in BKD from 6 out of 8 hatcheries over $5 \mathrm{yr}$, in this case attributed to changes in hatchery practices. A monthly survey of wild Arctic charr Salvelinus alpinus covering $3 \mathrm{yr}$ in Iceland reported frequent but low levels of $R$. salmoninarum antigen, and suggested the bacterium has been endemic for a long period, and influenced by favourable ecological features of the lake system, in particular food conditions that result in decreased susceptibility to the bacterium (Jónsdóttir et al. 1998). In Norway, the significance of BKD is virtually negligible in farmed fish in freshwater or saltwater (T. T. Poppe, Norwegian School of Veterinary Science, Norway, pers. comm.). However, in countries rearing the more susceptible Pacific salmon Oncorhynchus spp., the situation is different. For example, in the United States the highest morbidity and mortality occur during hatchery rearing of Pacific salmon and this is a particular problem in chinook salmon O. tshawytscha. Consequently, many companies now rear Atlantic salmon Salmo salar in seawater net pens (D. G. Elliott, Western Fish Research Center, USA, pers. comm.).

Under current legislation, countries are allowed to implement measures to control BKD and other infectious diseases among farmed salmonids and to prevent movements of fish to other farms. In Scotland, this approach has been successful, as shown in the health status and the comparatively low number of BKD outbreaks recorded over the last $12 \mathrm{yr}$ (either in terms of the number of sites with DAOs or the number of positive cases). Therefore, legislation and continued control of BKD is considered a priority within the current 
legislative framework. A decline in the number of DAOs placed may also be reflected in a change in the prevalence of BKD. Overall, it appears that the incidence of revocations has exceeded the incidence of new orders. Likewise, the incidence of revocations of DAOs is also low. The number of DAOs in force for rainbow trout has remained relatively constant over the period of study. The number of new sites subject to a DAO has been low, and has never exceeded more than 1 farm in any year. It is concluded from these observations that the DAOs in force are maintained by a small number of farms that are unable to eliminate the disease. There is no evidence to suggest that changes in surveillance effort were associated with a move from routine testing to active surveillance after 1995, as there were only 2 outbreaks of BKD diagnosed in 1996 in salmon, and none in trout. Some farms, particularly those rearing rainbow trout in freshwater, have long-term DAOs in operation. For example, 9 sites have had official orders in place since 1992. Recurring outbreaks of sub-clinical BKD may not be recorded each year as some site visits occur outside the periods when clinical disease is likely. DAOs may also extend over more than $1 \mathrm{yr}$, especially in the absence of fallowing and when there are overlapping generations of fish on a farm. This is particularly so for the trout industry compared to the salmon industry since the latter, by and large, practices a fallowing strategy in seawater and an all-in, all-out regime in freshwater.

The low number of sporadic and confirmed cases of BKD in salmon stocks are considered to be related to the legislation in place and the increasing practice of regular fallowing, particularly of marine sites. Fallowing helps to break disease cycles, eliminating infection and the potential for outbreaks in subsequent generations. This aspect is considered important as this bacterium is vertically transmitted (Bruno \& Munro 1986b, Evelyn et al. 1986). Within the trout industry, however, there are clear indications that infection can remain on freshwater sites over several years, where either there is an overlap of generations with seasonal outbreaks or where fallowing is not generally practised.

Acknowledgements. Thanks are due to the Fish Health Inspectorate at FRS for supplying data relating to designated area orders (DAOs).

\section{LITERATURE CITED}

Austin B, Embley TM, Goodfellow M (1983) Selective isolation of Renibacterium salmoninarum. FEMS Microbiol Lett 17:111-114

Banner CR, Long JJ, Rohovec J S (1986) Occurrence of salmonid fish infected with Renibacterium salmoninarum in the Pacific Ocean. J Fish Dis 9:273-275

Editorial responsibility: Otto Kinne (Managing Editor), Oldendorf/Luhe, Germany
Brown LC, Albright LJ, Evelyn TPT (1990) Control of vertical transmission of Renibacterium salmoninarum by injection of antibiotics into maturing female coho salmon, Oncorhynchus kisutch. Dis Aquat Org 9:127-131

Bruno DW (1986a) Histopathology of bacterial kidney disease in laboratory infected rainbow trout, Salmo gairdneri, Richardson, and Atlantic salmon, Salmo salar L. J Fish Dis 9:23-537

Bruno DW (1986b) Scottish experience with bacterial kidney disease in farmed salmonids between 1976 and 1985. Aquacult Fish Manage 17:85-190

Bruno DW, Brown LL (1999) The occurrence of Renibacterium salmoninarum within vaccine adhesion components from Atlantic salmon, Salmo salar L. and coho salmon, Oncorhynchus kisutch Walbaum. Aquaculture 170:1-5

Bruno DW, Munro ALS (1986a) Uniformity in the biochemical properties of Renibacterium salmoninarum isolates obtained from several sources. FEMS Microbiol Lett 33:47-250

Bruno DW, Munro ALS (1986b) Observations on Renibacterium salmoninarum and the salmonid egg. Dis Aquat Org 1:83-87

Daly JG, Griffiths SG, Kew AK, Moore AR, Olivier G (2001) Characterization of attenuated Renibacterium salmoninarum strains and their use as live vaccines. Dis Aquat Org 44:21-126

Elliott DG, Pascho RJ, Bullock GL (1989) Developments in the control of bacterial kidney disease of salmonid fishes. Dis Aquat Org 6:201-215

Evelyn TPT, Ketcheson JE, Prosperi-Porta L (1984) Further evidence for the presence of Renibacterium salmoninarum in salmonid eggs and the failure of povidone-iodine to reduce intra-ovum infection rate in water-hardened eggs. J Fish Dis 7:173-182

Evelyn TPT, Prosperi-Porta L, Ketcheson JE (1986) Experimental intra-ovum infection of salmonid eggs with Renibacterium salmoninarum and vertical transmission of the pathogen with such eggs despite their treatment with erythromycin. Dis Aquat Org 1:97-202

Fryer JL, Sanders JE (1981) Bacterial kidney disease of salmonid fish. Annu Rev Microbiol 35:73-298

Griffiths SG, Melville KJ, Salonius K (1998) Reduction of Renibacterium salmoninarum culture activity in Atlantic salmon following vaccination with avirulent strains. Fish Shellfish Immunol 8:607-619

Jónsdóttir H, Malmquist HJ, Snorrason SS, Gudergsson G, Gudmundsdóttir S (1998) Epidemiology of Renibacterium salmoninarum in wild Arctic charr and brown trout in Iceland. J Fish Biol 53:322-339

Maule AG, Rondorf DW, Beeman J, Haner P (1996) Incidence of Renibacterium salmoninarum infections in juvenile hatchery spring chinook salmon in the Columbia and Snake rivers. J Aquat Anim Health 8:37-46

Mitchum DL, Sherman LE, Baxter GT (1979) Bacterial kidney disease in feral population of brook trout (Salvelinus fontinalis), brown trout (Salmo trutta), and rainbow trout (Salmo gairdneri). J Fish Res Board Can 36:1370-1376

Piganelli JD, Wiens GD, Zhang JA, Christensen JM, Kaattari SL (1999) Evaluation of a whole cell, p57-vaccine against Renibacterium salmoninarum. Dis Aquat Org 36:37-44

Pippy JHC (1969) Kidney disease in juvenile Atlantic salmon (Salmo salar) in the Margaree river. J Fish Res Board Can 26:2535-2537

Smith IW (1964) The occurrence and pathology of Dee disease. Freshwater and Salmon Fisheries Research, 34. Her Majesty's Stationery Office, Edinburgh

Submitted: October 8, 2003; Accepted: January 8, 2004

Proofs received from author(s): April 19, 2004 